\title{
ST
}

Science \& Technology

PAPER - OPEN ACCESS

\section{Pengembangan Modul Berbasis Inkuiri Terbimbing Pada Materi Hukum Dasar Kimia Di Sekolah Menengah Atas}

\author{
Author : : Intan Pratiwi dkk., \\ DOI $\quad: 10.32734 /$ st.v2i1.340 \\ Electronic ISSN $\quad: 2654-7082$ \\ Print ISSN : :2654-7074
}

Volume 2 Issue 1 - 2018 TALENTA Conference Series: Science \& Technology (ST)

This work is licensed under a Creative Commons Attribution-NoDerivatives 4.0 International License.

Published under licence by TALENTA Publisher, Universitas Sumatera Utara

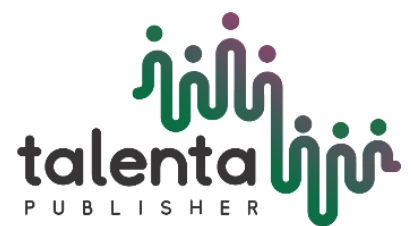


 \\ Pengembangan Modul Berbasis Inkuiri Terbimbing Pada Materi Hukum Dasar Kimia Di Sekolah Menengah Atas
}

\author{
Intan Pratiwi ${ }^{\mathrm{a}}$, Ratu Evina D ${ }^{\mathrm{b} *}$, Ramlan Silaban $^{\mathrm{c}}$, Retno Dwi Suyanti ${ }^{\mathrm{d}}$ \\ ${ }^{a}$ Alumni Pendidikan Kimia Universitas Negeri Medan, Medan \\ ratuevina1962@gmail.com
}

\begin{abstract}
Abstrak
Penelitianini bertujuan untuk mengetahui : 1) bahan ajar materi hukum dasar kimia pada buku yang digunakan di SMA/MA memenuhi kriteria Badan Standar Nasional Pendidikan (BSNP); 2) modul yang dikembangkan memenuhi kriteria BSNP; 3) uji coba modul berbasis inkuiri terbimbing dapat meningkatkan hasil belajar siswa; 4) hasil belajar siswa menggunakan modul berbasis inkuiri terbimbing lebih besar dari harga KKM. Penelitian ini dilakukan terhadap siswa kelas X SMA Negeri 14 Medan. Populasi yaitu seluruh siswa kelas X SMA Negeri 14 Medan Tahun Ajaran 2016/2017. Sampel ditetapkan dengan cluster random sampling dengan mengambil 1 kelas sebagai kelas eksperimen. Metode penelitian yang digunakan adalah metode penelitian dan pengembangan (Research and Development). Hasil penelitian menunjukkan : (1) bahan ajar pada materi hukum dasar kimia pada buku yang digunakan di SMA/MA sudah memenuhi kriteria BSNP dengan kriteria cukup valid dan tidak perlu revisi; (2) modul yang dikembangkan memenuhi kriteria BSNP, data yang diperoleh yaitu kelayakan isi = 3,68; kelayakan bahasa $=3,57$; kelayakan penyajian $=3,70$; kelayakan kegrafikaan $=3,50$ dengan kriteria valid dan tidak perlu revisi; (3) uji coba modul berbasis inkuiri terbimbing dapat meningkatkan hasil belajar siswa sebesar $80 \%$; (4) hasil belajar siswa menggunakan modul berbasis inkuiri terbimbing lebih besar dari harga KKM.
\end{abstract}

Kata kunci: Research and Development, modul, BSNP, pembelajaran berbasis inkuiri terbimbing, hasil belajar

\section{Pendahuluan}

Kimia didefinisikan sebagai ilmu yang mempelajari tentang susunan, struktur, sifat dan perubahan materi, serta energi yang menyertai perubahan tersebut. Dalam pembelajaran kimia, senantiasa berhadapan dengan masalah dan memecahkannya secara sistematis, seringkali masalah dalam ilmu kimia tergolong rumit dan kompleks sehingga ada kesan bahwa ilmu kimia adalah ilmu yang sukar [1]. Berdasarkan observasi yangdi lakukan di SMA Negeri diMedan, kimia merupakan salah satu mata pelajaran yang sulit dimengerti oleh para siswa. Berdasarkan data hasil ulangan tengah semester tahun ajar 2015/ 2016 yang telah dilakukan, masih banyak siswa yang tidak tuntas dalam mata pelajaran kimia. Hanya 13 dari 37 siswa yang tuntas dengan KKM 75, hal ini disebabkan karena buku pegangan kimia tidak dimiliki oleh para siswa. Buku Kimia Kurikulum 2013 dibagikan kepada siswa hanya pada saat proses pembelajaran kimia dikelas. Setelah selesai pembelajaran, buku akan dikembalikan ke perpustakaan sekolah, sehingga siswa tidak memiliki buku pegangan untuk menghadapi materi pelajaran selanjutnya. Guru juga cenderung menerapkan metode konvensional mengakibatkan pembelajaran dikelas cenderung monoton dan membosankan.

Nilai kimia yang rendah disebabkan karena penyampaian materi dalam pembelajaran tidak secara luas, kegiatan siswa masih sepenuhnya menyimak, mencatat dan latihan soal, dan ketergantungan siswa terhadap guru masih besar [2]. Penggunaan metode pembelajaran yang cenderung monoton dan kurangnya keterlibatan siswa dalam menemukan suatu konsep dalam proses pembelajaran juga menjadi penyebab kimia kurang menarik bagi siswa. Pembelajaran lebih terkesan bersifat teacher-centered, guru hanya menyampaikan materi sebagai produk dan siswa menghafal informasi factual [3].

Menurut Tiring [4], untuk mengatasi masalah tersebut, diperlukan suatu model pembelajaran yang menarik, 
menyenangkan dan mengembangkan kemampuan berpikir (minds on activity). Wardan [5] mengungkapkan bahwa salah satu model pembelajaran yang efektif adalah Inkuiri. Metode Inkuiri adalah cara penyampaian bahan pengajaran dengan memberi kesempatan kepada siswa untuk belajar mengembangkan potensi intelektualnya dalam menemukan sesuatu sebagai jawaban terhadap permasalahan yang dihadapkan kepadanya melalui proses pelacakan informasi. Dilihat dari keterlibatan guru dalam proses pembelajaran, ada tiga jenis model inkuiri; yaitu inkuiri terbimbing, inkuiri bebas, dan inkuiri bebas termodifikasi.

Inkuiri terbimbing digunakan terutama bagi siswa yang belum mempunyai pengalaman belajar dengan metode inkuiri. Dalam hal ini guru memberikan bimbingan dan pengarahan yang cukup luas. Dalam pelaksanaannya, sebagian besar perencanaan dibuat oleh guru dan para siswa tidak merumuskan permasalahan. Berdasarkan hal tersebut, pada penelitian ini saya menggunakan model inkuiri terbimbing. Berdasarkan model pembelajaran inkuiri terbimbing ini, dapat dikembangkan suatu bahan ajar berupa modul [6].

Modul adalah bahan pembelajaran yang dapat mendorong dan memberikan siswa kesempatan untuk belajar secara mandiri dan belajar secara tepat sesuai dengan kemampuan siswa [7]. Pada penelitian ini dikembangkan modul berbasis inkuiri terbimbing, yaitu modul yang menyajikan materi dan masalah dengan menggunakan metode investigasi dimana siswa dibimbing untuk dapat menemukan konsep materi yang dipelajari oleh mereka sendiri [5].

Materi kimia yang dianggap sulit oleh siswa salah satunya adalah hukum dasar kimia. Materi hukum dasar kimia masuk dalam materi kelas X semester genap pada kurikulum 2013 yang merupakan materi hitungan dan terdapat reaksi-reaksi sederhana. Materi hukum dasar kimia berisi tentang sejarah, konsep teori dan banyak sekali perhitungan. Sehingga dengan adanya modul berbasis inkuiri terbimbing ini, siswa dapat lebih mudah dalam mempelajari hukum dasar kimia [8].

Penelitian bahan ajar berbasis Inkuiri Terbimbing telah banyak dilakukan oleh peneliti terdahulu, seperti penelitian yang dilakukan oleh Tiring [4], membuktikan bahwa modul kimia berbasis inkuiri terbimbing efektif untuk meningkatkan hasil belajar siswa baik pengetahuan, sikap dan keterampilan pada materi ajar identifikasi gugus fungsi. Penelitian tentang modul ini juga dilakukan oleh Wardani [5] yang membuktikan bahwa modul kimia pembelajaran inkuiri terbimbing pada materi larutan penyangga efektif dalam meningkatkan konsep pemahaman siswa dan meningkatkan karakter siswa. Penelitian Isworini [2] menunjukkan bahwa modul berbasis inkuiri terbimbing yang dikembangkan layak digunakan untuk pembelajaran hidrolisis garam.

Berdasarkan pada uraian di atas, penulis tertarik untuk melakukan penelitian yang berjudul "Pengembangan Modul Berbasis Inkuiri Terbimbing Pada Materi Hukum Dasar Kimia di Sekolah Menengah Atas".

\section{Metode}

Model Pengembangan. Model pengembangan yang digunakan dalam pengembangan modul kimia berbasis inkuiri terbimbing ini adalah Development Research. Produk yang dikembangkan berupa modul kimia berbasis inkuiri terbimbing pada materi Hukum Dasar Kimia. Menurut Gay [9] development research adalah suatu usaha untuk mengembangkan suatu produk yang efektif untuk digunakan sekolah, dan bukan untuk menguji teori. Sedangkan Seels dalam Richey [10], mendefinisikan development research sebagai suatu pengkajian sistematik terhadap pendesainan, pengembangan dan evaluasi program, proses dan produk pembelajaran yang harus memenuhi kriteria validitas, kepraktisan, dan efektifitas. Development research ini mengacu pada model pengembangan bahan ajar 4-D (four-D Model) yang dikemukakan oleh Thiagarajan dan Semmel tahun 1974 yang terdiri dari empat tahapan yaitu tahap pendefinisian (define), tahap perancangan (design), tahap pengembangan (develop), dan tahap penyebaran (disseminate). Model pengembangan 4-D digunakan peneliti karena tahapan penelitian pengembangan 4-D memiliki kelebihan, yaitu dalam model 4-D melibatkan analisis materi dan analisis tugas dalam menentukan tujuan pembelajaran khusus, sehingga akan memudahkan dalam menjabarkan tujuan pembelajaran umum ke tujuan pembelajaran khusus. Model pengembangan ini sudah terfokus pada pengembagan bahan ajar.

Populasi dan Sampel. Populasi adalah keseluruhan subjek penelitian. Populasi dalam penelitian ini adalah seluruh siswa kelas X SMA Negeri 14 Medan. Sedangkan sampel merupakan sebagian atau wakil populasi yang akan diteliti. Satu kelas kelas X terpilih sebagai sampel eksperimen yang ditentukan secara acak sederhana (Simple Random Sampling) untuk mendapatkan kelas sampel yang reperesentatif.

Intrumen Penelitian.Instrumen yang digunakan dalam penelitian pengembangan ini yaitu soal tes, dan lembar validasi. Pengolahan data dalam penelitian ini dilakukan dengan menggunakan analisis deskriptif, meliputi analisis kelayakan dan analisis data hasil tes belajar. Metode pengumpulan data dalam penelitian ini adalah dengan teknik angket untuk mengetahui kelayakan modul dari dosen dan guru sebagai validator ahli, penilaian hasil belajar 
keterampilan dan sikap, dan teknik tes untuk penilaian hasil belajar pengetahuan.

\section{Hasil dan Pembahasan}

\section{Analisis Buku Kimia}

Analisis ketiga buku kimia oleh peneliti didasarkan pada silabus kurikulum 2013. Pada table berikut dijelaskan alasan pemilihan ketiga buku kimia yang telah dianalisis peneliti.

Tabel 1. Jenis Buku Kimia yang Digunakan dalam Pengembangan Modul. Disertai dengan alasan penulis dalam pemilihan buku.

\begin{tabular}{lll}
\hline Judul Buku & Pengarang/Penerbit & Alasan Pemilihan Buku \\
\hline KIMIA Untuk & H Watoni / CV.YRAMA WIDYA & $\begin{array}{l}\text { Buku yang digunakan sebagai buku } \\
\text { pegangan di SMA penelitian }\end{array}$ \\
SMA/MA Kelas X & & Budi Utami / Pusat Perbukuan \\
\hline KIMIA Untuk & $\begin{array}{l}\text { Buku yang sering digunakan sebagai bahan } \\
\text { ajar pada tingkat SMA }\end{array}$ \\
SMA/MA Kelas X & Departemen Pendidikan Nasional & $\begin{array}{l}\text { Buku yang sering digunakan sebagai bahan } \\
\text { ajar pada tingkat SMA }\end{array}$ \\
\hline KIMIA Berbasis & S.B Rahardjo / Platinum & \\
Eksperimen 1 Untuk & & \\
Kelas X SMA /MA & &
\end{tabular}

\section{Analisis Buku Kimia Oleh Guru}

Setelah peneliti menganalisis sendiri ketiga buku tersebut, kemudian buku tersebut juga dianalisis oleh tiga guru kimia SMA N 14 Medan dengan menggunakan instrumen BSNP untuk melihat kelayakan isi, kelayakan bahasa, kelayakan penyajian dan kelayakan kegrafikaan. Ketiga buku diberi kode Buku 1, Buku 2, dan Buku 3. Data yang diperoleh berupa daftar check list, dimana responden memberikan tanda ceklis $(\checkmark)$ pada kolom yang sesuai. Hasil penilaian tiga buku kimia berdasarkan komponen kelayakan isi, kelayakan bahasa, kelayakan penyajian dan kelayakan kegrafikaan secara keseluruhan dapat dilihat pada tabel 2.

Tabel 2. Hasil Penilaian Tiga Buku Oleh Guru Kimia. Hasil penilaian diambil dari rata-rata kriteria kelayakan BSNP.

\begin{tabular}{lccccc}
\hline \multirow{2}{*}{ Buku Teks } & \multicolumn{4}{c}{ Rata-Rata Skor Standar Kesesuaian Materi } & \multirow{2}{*}{ Rata-Rata } \\
\cline { 2 - 5 } & $\begin{array}{c}\text { Kelayakan } \\
\text { Isi }\end{array}$ & $\begin{array}{c}\text { Kelayakan } \\
\text { Bahasa }\end{array}$ & $\begin{array}{c}\text { Kelayakan } \\
\text { Penyajian }\end{array}$ & $\begin{array}{c}\text { Kelayakan } \\
\text { Kegrafikaan }\end{array}$ & \\
\hline Buku 1 & 3,11 & 3,21 & 3,09 & 3,02 & 3,11 \\
\hline Buku 2 & 2,94 & 3,10 & 3,00 & 3,00 & 3,01 \\
\hline Buku 3 & 3,05 & 3,19 & 3,05 & 3,02 & 3,08 \\
\hline
\end{tabular}

Berdasarkan data hasil analisis penilaian tiga buku kimia (buku 1, buku 2, dan buku 3), maka dapat diperoleh grafik perbandingan hasil analisis tiga buku kimia sebagai berikut:

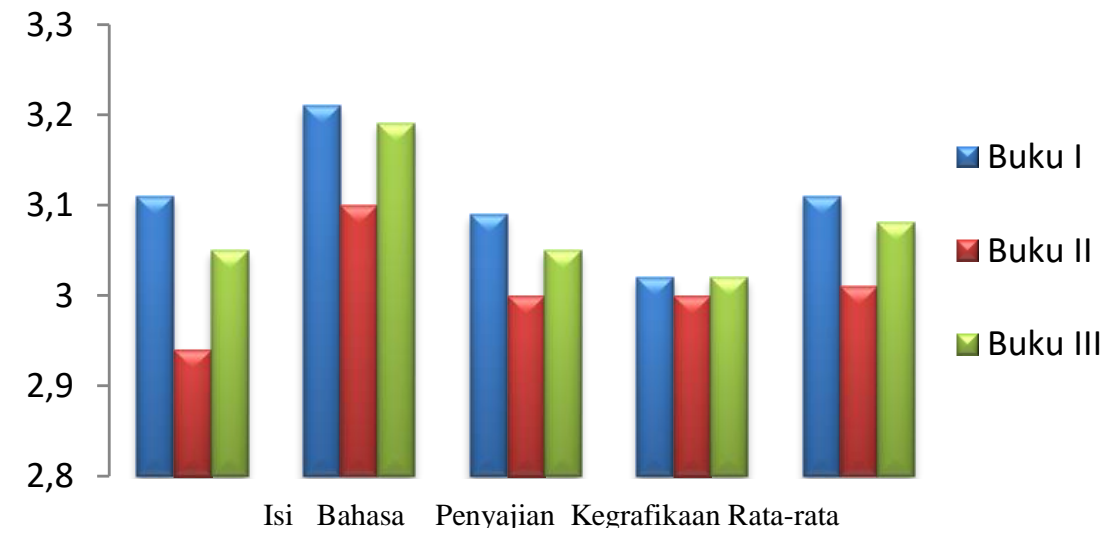

Gambar 1. Grafik Hasil Analisis Tiga Buku Kimia Oleh Guru Kimia. Ketiga buku kimia termasuk dalam kriteria Cukup layak dan tidak perlu revisi. 


\section{Perancangan dan Pengembangan Modul}

Setelah dilakukan analisis buku, langkah selanjutnya adalah perancangan dan pengembangan modul. Perancangan modul didasarkan pada silabus 2013 dan hasil analisis buku. Kelebihan dari masing-masing buku diambil untuk digunakan dalam perancangan dan pengembangan modul. Modul dikembangkan dengan beberapa referensi dari internet yang sesuai dengan subjek dalam modul.

\section{Standarisasi Modul}

Standarisasi dilakukan dengan menggunakan instrumen BSNP Inkuiri. Terbimbing sehingga diperoleh hasil penilaian dan saran perbaikan. Kemudian setelah mendapat hasil penilaian, modul yang dikembangkan kembali direvisi sesuai dengan hasil penilaian.Standarisasi modul dilakukan oleh tiga dosen FMIPA UNIMED Jurusan Kimia yaitu Ibu Prof. Dr. Retno Dwi Suyanti, M.Si, Bapak Dr. Ajat Sudrajat, M.Si, dan Ibu Nora Susanti, S.Si, Apt, M.Sc dan empat guru kimia SMA Negeri 14 Medan, Ibu Sofiah Bangun, S.Pd, M.Si, Bapak Drs. Tumpal Lumban Tobing, Ibu Rosalinda Pardede S.Pd, dan Ibu Dra. Debora. Hasil keseluruhan mengenai tanggapan penilai mengenai modul berbasis Inkuiri Terbimbing disajikan dalam tabel berikut :

Tabel 3. Hasil Penilaian Kelayakan Isi Modul. Kriteria penilaian diambil dari BSNP.

\begin{tabular}{clc}
\hline Unsur Penilaian & \multicolumn{1}{c}{ Komponen Yang Dinilai } & Rata-Rata \\
\hline Kelayakan Isi & Pengorganisasian bahan ajar & 3,78 \\
\cline { 2 - 3 } & Cakupan Materi & 3,61 \\
\cline { 2 - 3 } & Kebenaran konsep & 3,53 \\
\cline { 2 - 3 } & Muatan isi bahan ajar & 3,78 \\
\hline Rata-Rata Keseluruhan Kelayakan Isi & 3,68 \\
\hline
\end{tabular}

Berdasarkan penilaian kelayakan isi terhadap modul berbasis inkuiri terbimbing pada materi hukum dasar kimia diperoleh rata-rata dari komponen kelayakan isi adalah 3,68 dengan kriteria layak dan tidak perlu revisi.

Tabel 4. Hasil Penilaian Kelayakan Bahasa. Modul Kriteria penilaian diambil dari BSNP.

\begin{tabular}{clc}
\hline Unsur Penilaian & \multicolumn{1}{c}{ Komponen Yang Dinilai } & Rata-Rata \\
\hline Kelayakan Bahasa & Sesuai dengan Perkembangan Peserta Didik & 3,43 \\
\cline { 2 - 3 } & Aspek Kejelasan Kalimat Dan Tingkat Keterbacaan & 3,57 \\
\cline { 2 - 3 } & Aspek Penulisan & 3,57 \\
\cline { 2 - 3 } & Aspek Penggunaan Bahasa, Istilah Dan Symbol & 3,71 \\
\hline Rata-Rata Keseluruhan Kelayakan Bahasa & 3,57 \\
\hline
\end{tabular}

Berdasarkan penilaian kelayakan bahasa terhadap modul berbasis inkuiri terbimbing pada materi hukum dasar kimia rata-rata dari komponen kelayakan bahasa adalah 3,57 dengan kriteria layak dan tidak perlu revisi.

Tabel 5. Hasil Penilaian Penyajian Modul. Kriteria penilaian diambil dari BSNP.

\begin{tabular}{clc}
\hline Unsur Penilaian & \multicolumn{1}{c}{ Komponen Yang Dinilai } & Rata-Rata \\
\hline Kelayakan Penyajian & Komponen bahan ajar & 3,57 \\
\cline { 2 - 3 } & Daya tarik Bahan Ajar & 3,71 \\
\cline { 2 - 3 } & Aspek penyajian bahan ajar & 3,85 \\
\cline { 2 - 3 } & Sintaks inkuiri terbimbing dalam bahan ajar & 3,67 \\
\hline Rata-Rata Keseluruhan Kelayakan Penyajian & 3,70 \\
\hline
\end{tabular}

Berdasarkan penilaian kelayakan penyajian modul terhadap modul berbasis inkuiri terbimbing pada materi hukum dasar kimia diperoleh rata-rata yang didapat dari komponen kelayakan penyajian modul adalah 3,70 dengan kriteria layak dan tidak perlu revisi. 
Tabel 6.Hasil Penilaian Kegrafikaan Modul. Kriteria penilaian diambil dari BSNP.

\begin{tabular}{clc}
\hline \multicolumn{1}{c}{ Unsur Penilaian } & \multicolumn{1}{c}{ Komponen Yang Dinilai } & Rata-Rata \\
\hline Kelayakan Kegrafikaan & $\begin{array}{l}\text { Ukuran buku } \\
\text { (sesuai standar ISO, kesesuaian materi dengan isi buku) }\end{array}$ & 3,43 \\
\cline { 2 - 3 } & $\begin{array}{l}\text { Desain kulit buku } \\
\text { (tata letak, pusat pandang, komposisi seimbang, warna, } \\
\text { konsisten dalam satu materi) }\end{array}$ & 3,57 \\
\hline \multicolumn{2}{l}{ Rata-Rata Keseluruhan Kelayakan Kegrafikaan } & 3,50 \\
\hline
\end{tabular}

Berdasarkan penilaian kelayakan kegrafikaan terhadap modul berbasis inkuiri terbimbing pada materi hukum dasar kimia diperoleh rata-rata yang didapat dari komponen kelayakan kegrafikaan adalah 3,50 dengan kriteria layak dan tidak perlu revisi.

Hasil penilaian standarisasi modul berbasis inkuiri terbimbing pada materi hukum dasar kimia yang dikembangkan berdasarkan kelebihan dan kelemahan buku yang dianalisis yang sesuai dengan komponen materi modul, baik dari dosen maupun guru yang disajikan berdasarkan semua deskripsi penilaian yang sesuai dengan standar kesesuaian materi. Setiap deskripsi penilaian dihitung rata-rata nilainya dari kedua kalangan tim penilai yang kemudian pada akhir penilaian dihitung rata-rata semua deskripsinya sehingga diketahui nilai akhir dari bahan ajar berbasis inkuiri terbimbing pada materi hukum dasar kimia, yaitu :

Tabel 7. Hasil Standarisasi Modul. Modul yang telah dikembangkan termasuk dalam kriteria Layak dan tidak perlu revisi.

\begin{tabular}{clcl}
\hline No. & \multicolumn{1}{c}{ Kriteria } & Rata-rata & Kriteria Kelayakan \\
\hline 1. & Kelayakan Isi & 3,68 & Layak dan tidak perlu revisi \\
\hline 2. & Kelayakan Bahasa & 3,57 & Layak dan tidak perlu revisi \\
\hline 3. & Kelayakan Penyajian & 3,70 & Layak dan tidak perlu revisi \\
\hline 4. & Kelayakan Kegrafikan & 3,50 & Layak dan tidak perlu revisi \\
\hline & Rata-Rata & $\mathbf{3 , 6 1}$ & Layak dan tidak perlu revisi \\
\hline
\end{tabular}

\section{Hasil Uji Coba Modul Yang Dikembangkan}

Berdasarkan hasil perhitungan diperoleh data statistik hasil belajar siswa yang dirangkum dalam tabel statistik deskriptif pada tabel 8 .

Tabel 8. Rangkuman Statistik Deskriptif Hasil Belajar Siswa

\begin{tabular}{ccc}
\hline \multirow{2}{*}{ Data } & Statistik & $\begin{array}{c}\text { Kelas Eksperimen } \\
\text { (Satu Kelompok Sampel) }\end{array}$ \\
\hline \multirow{5}{*}{ Pretest } & Rata-rata & 38,75 \\
\cline { 2 - 3 } & Standar deviasi & 10,51 \\
\cline { 2 - 3 } & Varians & 110,54 \\
\cline { 2 - 3 } & Nilai minimum & 10 \\
\cline { 2 - 3 } & Nilai maksimum & 65 \\
\cline { 2 - 3 } & Nilai total & 1395 \\
\hline \multirow{3}{*}{ Posttest } & Rata-rata & 87,64 \\
& Standar deviasi & 7,22 \\
\cline { 2 - 3 } & Varians & 52,12 \\
\cline { 2 - 3 } & Nilai minimum & 75 \\
\cline { 2 - 3 } & Nilai maksimum & 100 \\
\cline { 2 - 3 } & Nilai total & 3155 \\
\hline
\end{tabular}


Berdasarkan Tabel diatas, maka diperoleh nilai rata-rata pretest siswa yaitu 38,75 dan nilai rata-rata posttest siswa yaitu 87,64. Nilai standar deviasi pretes yaitu 10,51 dan nilai varians pretes yaitu 110,54. Nilai standar deviasi posttes yaitu 7,22 dan nilai varians posttes yaitu 52,12. Standar deviasi yakni besar perbedaan dari nilai sampel terhadap rata-rata. Dan Varians adalah simpangan baku yang dikuadratkan.

Dari data perhitungan diatas maka dapat digambarkan hasil perolehan rata-rata nilai pretest dan nilai posttest kelas eksperimen melalui diagram pada Gambar 2 di bawah ini :

Gambar 2. Rata-Rata Hasil Belajar Siswa

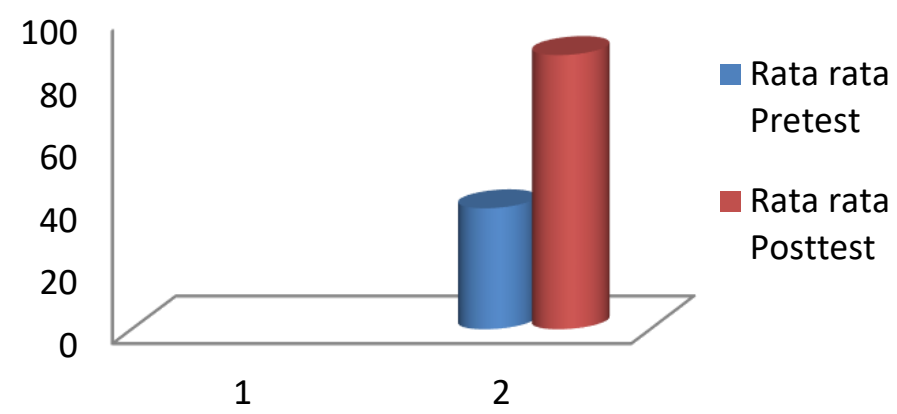

Dari diagram diatas didapat rata-rata pretest untuk kelas eksperimen (kelas uji coba modul) adalah 38,75. Setelah dilakukan pretest sampel diberi pembelajaran dan selanjutnya dilaksanakan posttest sehingga diperoleh ratarata posttest kelas eksperimen sebesar 87,64 kemudian diperoleh peningkatan hasil belajar masing-masing sampel yang menggunakan bahan ajar modul berbasis inkuiri terbimbing pada materi hukum dasar kimia.

\section{Peningkatan Hasil Belajar (Gain)}

Perhitungan peningkatan hasil belajar dapat diperoleh dari rata-rata nilai gain seluruh siswa kelas eksperimen dengan dikali 100\%. Perhitungan gain kelas eksperimen dapat dilihat pada Tabel 9. berikut:

Tabel 9. Hasil Perolehan Gain Kelas Eksperimen

\begin{tabular}{|c|c|c|c|c|}
\hline Kelas & Kriteria & $\begin{array}{c}\text { Rata- Rata } \\
\text { Gain }\end{array}$ & $\%$ Gain & Kriteria \\
\hline Eksperimen & $\begin{array}{c}\% \mathrm{~g}<30=\text { Rendah } \\
30<\% \mathrm{~g}>70=\text { Tinggi } \\
\% \mathrm{~g}>70=\text { Tinggi }\end{array}$ & 0,80 & $80 \%$ & Tinggi \\
\hline
\end{tabular}

Berdasarkan Tabel 9. dapat dilihat bahwa \% gain kelas eksperimen lebih besar dari 70 sehingga kriteria peningkatan hasil belajar siswa yang menggunakan modul berbasis inkuiri terbimbing pada materi hukum dasar kimia tergolong tinggi. Maka dapat disimpulkan bahwa penggunaan bahan ajar modul berbasis inkuiri terbimbing pada materi hukum dasar kimia dapat meningkatkan hasil belajar siswa.

\section{Uji Hipotesis}

Uji hipotesis dilakukan untuk mengetahui apakah hipotesis alternatif (Ha) diterima atau ditolak. Uji hipotesis yang akan di uji adalah uji hipotesis hasil belajar kimia menggunakan modul berbasis inkuiri terbimbing lebih besar dari harga KKM. Kriteria pengujian jika $t_{\text {hitung }}>t_{\text {tabel }}$ maka hipotesis alternatif diterima dan hipotesis nol ditolak. Data hasil uji hipotesis dapat dilihat pada tabel 10berikut : 
Tabel 10. Hasil Uji Hipotesis Hasil Belajar dengan Harga KKM

\begin{tabular}{llll}
\hline $\begin{array}{c}\text { Data Posttest Kelas } \\
\text { Eksperimen }\end{array}$ & $\mathbf{t}_{\text {hitung }}$ & $\mathbf{t}_{\text {tabel }}$ & Keterangan \\
\hline$\overline{\mathrm{X}}=87,64$ & & & \\
$\mu_{0}=75$ & & & \\
$\mathrm{~s}=7,22$ & 10,507 & 1,696 & Ha diterima \\
$\mathrm{n}=36$ & & & \\
& & & \\
\hline
\end{tabular}

Dari hasil perhitungan data tabel diatas diperoleh nilai $t_{\text {hitung }}$ lebih besar daripada $t_{\text {tabel }}$ maka Ho ditolak yang artinya Ha diterima sehingga dapat disimpulkan bahwa hasil belajar kimia siswa yang diajarkan dengan menggunakan modul berbasis inkuiri terbimbing lebih besar dari harga KKM.

\section{Kesimpulan}

Berdasarkan hasil penelitian diperoleh kesimpulan sebagai berikut :

1. Bahan ajar pada materi hukum dasar kimia pada buku yang digunakan di SMA/MA sudah memenuhi kriteria Badan Standar Nasional Pendidikan (BSNP) dengan kriteria cukup valid dan tidak perlu revisi.

2. Modul yang dikembangkan memenuhi kriteria Badan Standar Nasional Pendidikan (BSNP), dengan pengolahan data yang diperoleh : kelayakan isi $=3,68$; kelayakan bahasa $=3,57$; kelayakan penyajian $=3,70$; kelayakan kegrafikaan $=3,50$ dengan kriteria valid dan tidak perlu revisi.

3. Uji coba modul pembelajaran berbasis inkuiri terbimbing dapat meningkatkan hasil belajar siswa dalam materi hukum dasar kimia di sekolah menengah atas.

4. Dari penelitian yang telah dilakukan dan berdasarkan pengolahan data yang ada, maka didapat hasil belajar kimia menggunakan modul berbasis inkuiri terbimbing lebih besar dari harga KKM.

\section{Referensi}

[1] Dewi, C.A., dan Handayani, T.F., (2015), Pengembangan Modul Kimia Berbasis Problem Based Research (PBR) pada Materi Larutan Elektrolit dan Nonelektrolit, Jurnal Pengkajian Ilmu dan Pembelajaran Matematika dan IPA "PRISMA SAINS"3(2):369 - 372

[2] Isworini., Sunarno, W., dan Saputro, S., (2015), Pengembangan Modul Pembelajaran Hidrolisis Garam Berbasis Model Inkuiri Terbimbing Untuk Siswa Madrasah Aliyah Kelas XI, Jurnal Inkuiri4(3) : 9 - 20

[3] Wibowo, T., Supartono., dan Supardi, K.I., (2015), Pengembangan Modul Termokimia dengan Pendekatan Inkuiri Terpadu Pendidikan Karakter untuk Meningkatkan Logika Siswa, Journal of Innovative Science Education4(1) : 1-6

[4] Tiring, S.S.N., Saputro, S., dan Utomo, S.B., (2015), Pengembangan Modul Kimia Berbasis Inkuiri Terbimbing Pada Materi Identifikasi Gugus Fungsi Kelas X SMK Kimia Industri, Jurnal Inkuiri4(3) : 51-59

[5] Wardani, S., Nurhayati, S., dan Safitri, A., (2015). The Effectiveness of the Guided Inquiry Learning Module towards Students' Character and Concept Understanding, International Journal of Science and Research (IJSR) 5(6) : I589-1594

[6] Budiada, I.W., (2012), Pengaruh Penerapan Model Pembelajaran Inkuiri Terbimbing Berbasis Asesmen Portofolio terhadap Hasil Belajar Kimia Siswa Kelas x Ditinjau Dari Adversity Quotient, Jurnal Penelitian dan Evaluasi Pendidikan2(1) : 8-24

[7] Novilia, L., Iskandar, S., dan Fajaroh, F., (2016), The Effectiveness of Colloid Module Based on Guided Inquiry Approach to Increase Students' Cognitive Learning Outcomes, International Journal of Education 9 (1) : 17-23

[8] Kurniawati, D., Masykuri, M., dan Saputro, S., (2016), Penerapan Model Pembelajaran Inkuiri Terbimbing Dilengkapi LKS untuk Meningkatkan Keterampilan Proses Sains dan Prestasi Belajar Pada Materi Pokok Hukum Dasar Kimia Siswa Kelas x MIA 4 SMA N 1 Karanganyar Tahun Pelajaran 2014/2015, Jurnal Pendidikan Kimia (JPK) 5(1) : 88-95

[9] Gay, L.R., (1990), Educational Evaluation and Measurement: Com-petecies for Analysis and Application Second Edition, Macmilan Publishing Compan, New York.

[10] Richey, Rita C., (2007), Design and Development Research, Lawrence, London. 